\title{
PENGARUH KEBIASAAN BELAJAR TERHADAP KEPUASAN HASIL UJIAN PADA MATA KULIAH KONSEP KEBIDANAN
}

\author{
Yunik Windarti \\ Fakultas Keperawatan dan Kebidanan \\ Universitas Nahdlatul Ulama Surabaya Jl. Smea 57 Surabaya \\ Email : yunikwinda@unusa.ac.id
}

\begin{abstract}
The effect of habitual learning towards satisfaction of the results of tests on the course concepts of midwifery. Factors influenced the results of tests from the satisfaction of learning activities that are done by the student itself. In fact, many of the students who learn only at certain times, especially during exams. This research aims to analyze the effect of habitual learning towards satisfaction of the results of tests on the course concepts of midwifery. Design of analytical research, the population of students of the Semester I Prodi D-III Kebidanan FKK UNUSA of 123 people, a large sample of 123 people, taken with a probability sampling technique with total sampling. Independent study habits variables, variable dependent satisfaction exam results. The data is analyzed using kruskal wallis test. The results showed almost entirely $(78,9 \%)$ students had the habit of learning outcomes and is almost entirely $(75,6 \%)$ students were declared not satisfied against the results of the test. The results of statistical tests obtained $\rho=0,023<\alpha=0,05, \mathrm{H}_{0}$ is rejected then it means there is a significant learning habits influence towards the satisfaction of the results tests on the course concepts of midwifery. The conclusion of this research study is not good habits will cause discontent against the examination results are obtained. For students is expected to change the habit of studying, focus more on the material obtained, multiply the reading, often visited the library, the science danmenimba from various media rather than just rely on from the material presented lecturer.
\end{abstract}

Abstrak : Pengaruh kebiasaan belajar terhadap kepuasan hasil ujian pada mata kuliah konsep kebidanan. Faktor kepuasan hasil ujian dipengaruhi dari kegiatan belajar yang dilakukan oleh mahasiswa itu sendiri. Kenyataannya, banyak mahasiswa yang belajar hanya pada waktu tertentu saja, terutama saat menjelang ujian. Penelitian ini bertujuan untuk menganalisis pengaruh kebiasaan belajar terhadap kepuasan hasil ujian pada mata kuliah konsep kebidanan. Desain penelitian analitik, populasinya mahasiswa Semester I Prodi D-III Kebidanan FKK UNUSA sebesar 123 orang, besar sampel 123 orang, diambil dengan tehnik probability sampling dengan total sampling. Variabel independent kebiasaan belajar, variabel dependent kepuasan hasil ujian. Data dianalisa menggunakan uji kruskal wallis. Hasil penelitian menunjukkan hampir seluruhnya $(78,9 \%)$ mahasiswa mempunyai kebiasaan belajar yang kurang baik dan hampir seluruhnya $(75,6 \%)$ mahasiswa menyatakan tidak puas terhadap hasil ujiannya. Hasil uji statistik didapatkan $\rho=0,023<\alpha=0,05$, maka $\mathrm{H}_{0}$ ditolak artinya terdapat pengaruh yang signifikan kebiasaan belajar terhadap kepuasan hasil ujian pada mata kuliah konsep kebidanan. Simpulan dari penelitian ini kebiasaan belajar yang kurang baik akan menimbulkan ketidakpuasan terhadap hasil ujian yang diperoleh. Bagi mahasiswa diharapkan merubah kebiasaan belajar, lebih fokus pada materi yang didapat, memperbanyak membaca, sering mengunjungi perpustakaan, danmenimba ilmu dari berbagai media bukan hanya mengandalkan dari materi yang disampaikan dosen.

Kata kunci : Kebiasaan belajar, kepuasaan hasil ujian 



\section{LATAR BELAKANG}

Indonesia merupakan negara berkembang dengan berbagai masalah yang dihadapi. Tuntutan untuk menyelesaikan masalah sangat dibutuhkan untuk mensejahterakan seluruh lapisan masyarakt baik di kota maupun di desa. Pemerataan pendidikan, mutu pendidikan, efisiensi pendidikan dan masalah relevansi pendidikan merupakan beberapa masalah yang dihadapi dimana sampai saat ini masih belum terselesaikan secara tuntas.

Dalam jalur pendidikan formal sangat diperlukan keseriusan dalam belajar untuk memperoleh ilmu yang maksimal. Tetapi yang sering dilupakan adalah seberapa penting kebutuhan belajar dalam upaya meningkatkan mutu hasil pendidikan. Mata kuliah konsep kebidanan pada program studi D-III Kebidanan, merupakan mata kuliah yang jumlah SKSnya bisa dikatakan cukup tinggi (4 SKS). Secara otomatis baik materi maupun prakteknya membutuhkan waktu yang cukup banyak dengan isi materi yang juga banyak.

Ada beberapa fenomena yang menarik dimana para peserta didik cenderung melakukan kegiatan belajar hanya jika mereka mau ada ujian saja. Banyak alasan yang dikemukakan terkait kebiasaan mereka dalam mempersiapkan diri menghadapi ujian. Kenyataan ini memang tidak dapat diabaikan karena meskipun teknologi sudah canggih, namun masih banyak ditemukan mahasiswa dengan nilai ujian kurang baik bahkan cenderung kurang.

Kebiasaan belajar ini akan mempengaruhi kepercayaan dirinya dalam menghadapi ujian. Setelah hasil ujian di umumkan oleh dosen, ada banyak reaksi yang di tampilkan oleh mahasiswa. Kepuasan dalam hal nilai hasil belajar yang didapatkan mahasiswa beragam, ada yang puas ada yang tidak puas (Muhibbin syah, 2010).

Kepuasaan seseorang seringkali berbeda antara yang satu dengan yang lain karena kepuasaan bisa bersifat subyektif dari orang tersebut, namun kepuasaan seseorang jika di kaitkan dengan usaha yang telah dia kerjakan sebelumnya mungkin saja akan bermakna meskipun hasil yang di inginkan tidak sesuai dengan harapan (Purwanto, 2011)
Desain penelitian yang digunakan adalah analitik. Populasinya semua mahasiswa semester 1 Prodi D-III Kebidanan Fakultas Keperawatan dan Kebidanan UNUSA sebesar 123 orang. Tehnik sampling dilakukan secara probability sampling dengan teknik total sampling.

Data dianalisis dengan menggunakan uji statistik kruskal wallis dengan menggunakan SPSS versi 20. Pengaruh dari variabel dependen dengan variabel independen ditunjukkan oleh nilai $\mathrm{p}$.

Penelitian ini dilaksanakan di Prodi D-

III Kebidanan semester I Fakultas Keperawatan dan Kebidanan UNUSA kampus A, yang beralamatkan di jalan Smea No 57 Surabaya. Waktu penelitian pada bulan Desember 2015 - Januari 2016. UNUSA mempunyai 6 Fakultas, yaitu Keperawatan dan Kebidanan, Kedokteran, Kesehatan, Ekonomi dan Bisnis, Keguruan dan Ilmu Pendidikan, dan Tehnik . Untuk memfasilitasi 14 program studi yang saat ini telah dibuka, UNUSA telah memiliki 2 kampus dengan fasilitas lengkap dan modern. Ditunjang laboratorium yang lengkap untuk tiap program studi, memiliki rumah sakit sendiri (RS. Islam Surabaya A. Yani dan RS. Islam Surabaya Jemursari). Fungsi rumah sakit tersebut selain sebagai fasilitas layanan kesehatan sivitas akademika UNUSA juga diperuntukan bagi kegiatan sarana praktek bagi seluruh program studi yang ada dalam menunjang pencapaian target kompetensi mahasiswa.

Kurikulum di UNUSA merupakan kurikulum yang up to date sesuai dengan tuntutan masyarakat modern dengan metode pembelajaran Kurikulum Berbasis Kompetensi (KBK) serta berorientasi pada kemandirian mahasiswa. UNUSA memiliki visi dan misi yang jelas, dan terus menerus menambah fasilitas dan program studi baru searah dengan pengembangan pendidikan dan kebutuhan masyarakat di masa depan.

\section{HASIL \& PEMBAHASAN}

\section{a. Hasil}

Tabel 1 Distribusi frekuensi responden menurut kebiasaan belajar di Prodi D-III Kebidanan FKK UNUSA tahun 2016

\section{METODE}




\begin{tabular}{|l|l|c|c|}
\hline No & \multicolumn{1}{|c|}{ Kebiasaan Belajar } & Frekuensi & Persentase (\%) \\
\hline 1. & Kurang Baik & 97 & 78,9 \\
2. & Baik & 26 & 21,1 \\
\hline Jumlah & 123 & 100 \\
\hline
\end{tabular}

Sumber: Data primer 2016

Pada tabel 1 di atas menunjukkan bahwa dari 123 responden hampir seluruhnya $(78,9 \%)$ mempunyai kebiasaan belajar yang kurang baik.

Tabel 2 Distribusi frekuensi responden menurut kepuasan hasil ujian di Prodi D-III Kebidanan FKK UNUSA tahun 2016

\begin{tabular}{|l|l|c|c|}
\hline No & \multicolumn{1}{|c|}{ Kepuasan Hasil Ujian } & Frekuensi & Persentase (\%) \\
\hline 1. & Tidak Puas & 93 & 75,6 \\
2. & Kurang Puas & 28 & 22,8 \\
3. & Puas & 2 & 1,6 \\
\hline Jumlah & 123 & 100 \\
\hline
\end{tabular}

Sumber : Data primer 2016

Pada tabel 2 menunjukkan bahwa dari 123 responden hampir seluruhnya $(75,6 \%)$ menyatakan tidak puas terhadap hasil ujiannya.

Tabel 3 Tabulasi silang pengaruh kebiasaan belajar terhadap kepuasan hasil ujian di Prodi D-III Kebidanan FKK UNUSA tahun 2016

\begin{tabular}{|c|c|c|c|c|}
\hline \multirow{3}{*}{$\begin{array}{l}\text { Kebiasaan } \\
\text { Belajar }\end{array}$} & \multicolumn{3}{|c|}{ Kepuasan Hasil Ujian } & \multirow{3}{*}{$\begin{array}{l}\text { Jumlah } \\
\text { n }(\%)\end{array}$} \\
\hline & Tidak Puas & Kurang Puas & Puas & \\
\hline & n $(\%)$ & n $(\%)$ & n $(\%)$ & \\
\hline Kurang Baik & $75(77,3)$ & $22(22,6)$ & $0(0,0)$ & $97(100)$ \\
\hline Baik & $18(69,2)$ & $6(23,1)$ & $2(7,7)$ & $26(100)$ \\
\hline Jumlah & $93(75,6)$ & $28(22,8)$ & $2(1,6)$ & $123(100)$ \\
\hline
\end{tabular}

Tabel 3 di atas menunjukkan bahwa dari 97 responden, yang melakukan kebiasaan belajar kurang baik hampir seluruhnya (77,3\%) menyatakan tidak puas terhadap hasil ujiannya, dan 26 responden yang melakukan kebiasaan belajar baik hanya sebagian kecil $(1,6 \%)$ yang menyatakan puas terhadap hasil ujianya.

\section{b. Pembahasan}

\section{Kebiasaan belajar}

Hasil penelitian juga menunjukkan, dari 123 responden hampir seluruhnya $(78,9 \%)$ mempunyai kebiasaan kurang baik dalam hal belajar. Kebiasaan belajar yang kurang baik ini disebabkan beberapa hal, yaitu karena perilaku yang sudah terdidik dari kecil, sehingga mempengaruhi mereka dalam hal belajar. Selain itu, komitmen yang kurang tentang pentingnya belajar secara kontinyu. Secara umum responden mengerti tentang pentingnya belajar, tetapi karena ada banyak hal yang terjadi dalam kesehariannya, responden tidak bisa belajar dengan baik. Faktor suka dan tidak suka terhadap suatu mata kuliah juga bisa menjadi penyebab responden tidak bisa belajar dengan baik, dimana hal ini banyak penyebabnya misalnya bahan belajar yang terlalu banyak, bersifat terlalu konseptual, dan lain - lain.

Umur responden dalam penelitian ini 17 23 tahun dimana menurut WHO dalam kategori remaja akhir. Usia ini berhubungan dengan kebiasaan belajar. Hal ini sesuai teori menyatakan semakin tinggi usiannya anak menjadi lebih bertanggungjawab atas proses belajar karena kebiasaan termasuk di dalamnya sehingga disiplin belajar menjadi semakin penting (Nasution, 2005).

Kebiasaan adalah perbuatan berulangulang dengan bentuk yang sama yang dilakukan secara sadar dan mempunyai tujuantujuan jelas sehingga disukai banyak orang. Selain tidak belajar setiap hari, sebanyak $37 \%$ responden juga menyatakan jika sedang belajar tidak sampai paham dan tidak sampai tuntas sehingga mudah lupa. Seseorang yang belajar dengan sungguh - sungguh, tuntas, dan berkelanjutan akan terbiasa dan tidak mudah lupa terhadap materi kuliah yang di dapat (Sujatmiko, 2014).

\section{Kepuasaan hasil ujian}

Hasil penelitian menunjukkan menunjukkan bahwa dari dari 123 responden hampir seluruhnya $(75,6 \%)$ menyatakan tidak puas terhadap nilai hasil ujiannya. Hal tersebut menunjukkan bahwa responden kecewa terhadap hasil ujian yang diperolehnya. Kekecewaan ini terjadi karena nilai yang mereka harapkan tidak sesuai dengan kenyataannya. Hal ini sesuai dengan teori yang menyatakan bahwa kepuasan akan timbul bila kebutuhan individu terpenuhi, namun sebaliknya bila kebutuhan dan harapan tidak terpenuhi akan dapat menimbulkan ketidakpuasan (Wibowo, 2007).

Kepuasan merupakan sesuatu yang bersifat individual, merupakan salah satu unsur psikis, karena di dalam kepuasan yang berperan adalah perasaan. Hal ini terlihat pada quesioner dimana reponden dengan nilai 68 menyatakan tidak puas dengan nilai yang 
diperolehnya, tetapi ada juga responden yang menyatakan puas meskipun hanya mendapat nilai 39. Setiap individu memiliki tingkat kepuasan berbeda-beda sesuai dengan sistem nilai yang berlaku pada dirinya. Makin tinggi nilai terhadap kegiatan sesuai dengan keinginan individu, maka makin tinggi kepuasannya terhadap kegiatan tersebut.

\section{Pengaruh kebiasaan belajar terhadap kepuasaan hasil ujian}

Hasil uji kruskal wallis didapatkan nilai $\mathrm{p}$ $=0,023$ dan $\alpha=0,05$. Karena $\mathrm{p}(0,023)<\alpha$ (0.05), maka hipotesis nihil $\left(\mathrm{H}_{0}\right)$ ditolak yang artinya terdapat pengaruh yang signifikan kebiasaan belajar terhadap kepuasan hasil ujian pada mata kuliah konsep kebidanan.

Dari 97 responden, yang melakukan kebiasaan belajar kurang baik hampir seluruhnya $(77,3 \%)$ menyatakan tidak puas terhadap hasil ujiannya, dan 26 responden yang melakukan kebiasaan belajar baik hanya sebagian kecil $(1,6 \%)$ yang menyatakan puas terhadap hasil ujianya. Kebiasaan belajar yang kurang baik terbukti menyebabkan ketidakpuasan seseorang terhadap nilai hasil ujian yang dikerjakan. Kebiasaan belajar yang dilakukan mampu mempengaruhi nilai ujian, dimana dengan hasil ujian ini seseorang bisa merasa puas atau kurang puas atau bahkan tidak puas terhadap hasilnya. Dari quesioner diketahui bahwa beberapa responden yang menyatakan menyadari kesalahannya karena kurang rajin belajar dan berusaha untuk memperbaiki perilaku dan kebiasaan belajarnya. Ketidakpuasan seseorang dapat mendorong semangatnya untuk lebih meningkatkan potensi diri sehingga mampu mencapai keinginanya.

Keterlibatan siswa mempunyai dua unsur utama, yang pertama adalah jumlah waktu dan usaha yang digunakan siswa untuk belajar dan terlibat dalam kegiatan yang bertujuan pendidikan lainnya. Sedangkan, unsur yang kedua adalah bagaimana institusi pendidikan memberikan sumber dayanya dan mengorganisir kurikulum, kesempatan belajar lainnya dan dukungan fasilitas untuk mendorong siswa berpartisipasi dalam kegiatan yang memberikan pengalaman dan hasil yang diinginkan seperti ketekunan, kepuasan, pembelajaran dan kelulusan (Kuh, 2006).
Responden yang mempunyai kebiasaan belajar baik, ternyata hanya sebagian kecil saja yang merasa puas terhadap hasil ujiannya. Hal ini banyak dipengaruhi oleh tingginya harapan mereka terhadap nilai yang akan mereka peroleh. Selain itu kemungkinan karena faktor - faktor lain yang mempengaruhi pencapaian hasil belajar.

\section{SIMPULAN}

1. Mahasiswa Prodi D-III Kebidanan di FKK UNUSA hampir seluruhnya mempunyai kebiasaan belajar yang kurang baik.

2. Mahasiswa Prodi D-III Kebidanan di FKK UNUSA hampir seluruhnya menyatakan tidak puas terhadap hasil ujian pada mata kuliah konsep kebidanan.

3. Ada pengaruh yang signifikan kebiasaan belajar mahasiswa terhadap kepuasan hasil ujian mata kuliah konsep kebidanan pada Prodi D-III Kebidanan FKK UNUSA

\section{SARAN}

1. Bagi institusi pendidikan : Meningkatkan sumberdaya manusia, sarana dan prasarana, metode pembelajaran bervariasi, dan upaya meningkatkan ketertarikan mahasiswa terhadap semua matakuliah.

2. Bagi peneliti selanjutnya : Menjadi referensi dalam mengembangkan hasil penelitian selanjutnya tentang faktor-faktor lain yang mempengaruhi kepuasan hasil ujian

3. Bagi responden : Meningkatkan dan merubah kebiasaan belajar dari yang kurang baik menjadi baik, lebih fokus pada materi yang didapat, memperbanyak membaca dan mengunjungi perpustakaan, menimba ilmu dari berbagai media bukan hanya mengandalkan dari materi yang disampaikan dosen.

\section{DAFTAR PUSTAKA}

Kuh et al. 2006. What Matters to Student Success: A Review of the Literature, Commissioned Report for the National Symposium on Postsecondary Student Success

Muhibbin, Syah.2010. Psikologi Pendidikan dengan Pendekatan Baru. Bandung: PT Remaja Rosdakarya 
Murti, B. 2011. Validitas dan reliabilitas pengukuran. Fakultas Kedokteran Universitas Sebelas Maret Surakarta

Nasution. 2005. Berbagai Pendekatan dalam Proses Belajar dan Mengajar. Jakarta : Bumi Aksara

Sujatmiko, Eko. 2014. Kamus IPS. Surakarta:

Aksara Sinergi Media Cetakan 1.

Purwanto. 2011. Evaluasi hasil belajar. Yogyakarta : Pustaka Belajar

Wibowo. 2007. Manajemen Kinerja. Jakarta:

PT. Raja Grafindo Persada 